\title{
ENRICHING THE SOUNDSCAPE AND DANCESCAPE OF SABAH THROUGH SUMAZAU
}

\author{
${ }^{1}$ Hanafi Hussin*, ${ }^{2}$ Judeth John Baptist and ${ }^{3}$ Jacqueline Pugh-Kitingan \\ ( First author) \\ ${ }^{1}$ Department of Southeast Asian Studies, Faculty of Arts and Social Sciences, \\ Institute of Ocean and Earth Sciences (IOES), University of Malaya \\ ${ }^{2}$ Department of Sabah Museum, Kota Kinabalu, Sabah \\ ${ }^{3}$ Professor of Ethnomusicology, and Fellow of the Borneo Heritage Research Unit \\ Faculty of Humanities, Arts, and Heritage, \\ Universiti Malaysia Sabah \\ (hanafih@um.edu.my, judeth.baptist@sabah.gov.my, jacquie@ums.edu.my) \\ DOI: https://doi.org/10.22452/jati.vol23no2.9
}

\begin{abstract}
Sumazau is a generic term for a genre of music and dance of the Kadazan of Penampang District, Sabah. Traditionally, the sumazau was a sacred dance accompanied by distinctive gong music that was performed as part of religious ceremonies such as monogit, and those associated with rice farming, weddings, and various other obligatory rituals. The sumazau musical ensemble played using six hanging gongs, and a drum is called sompogogungan. When the sompogogungan plays the sumazau beat in ritual contexts, its sound is said to bridge the human and the spirit worlds. The dance itself, the sumazau, functions symbolically to cleanse and cure illness; the dancers embody the spiritual while simultaneously offering rice and rice wine to the spirits. Social change and development have made these traditional sacred practices less important in modern-day society. Nevertheless, sumazau continues to serve as a powerful identity symbol for the Kadazan. sumazau accompanied by the sompogogungan continues to be performed at village weddings and on other celebratory occasions, including special church events. Through staged performances featuring segments of the rituals choreographed for various secular events at district and state levels, Sumazau has become an iconic "living Kadazan heritage". sumazau music with its distinctive rhythm has also influenced popular music and contemporary Kadazan Dusun songs. Based on qualitative research among the Kadazan of Penampang, this paper discusses how sumazau music and
\end{abstract}


dance has been transformed from the sacred to the secular, from the traditionally private space to the public domain, where it enjoys a wider audience and participation as part of the intrinsic local popular culture of contemporary Sabah and Malaysia. Through concerted efforts to promote indigenous nationalism, sumazau music and dance have also become iconic cultural elements of the Kadazan as well as that of Sabah's identity.

Keywords: sumazau, musicscapes, dancescapes, heritage, identity, Kadazan of Sabah

\section{Introduction}

The Kadazan of Penampang is a branch of the Kadazan Dusun ethnic group of Sabah, Borneo. They speak the Coastal Kadazan dialect of the Kadazan Dusun language. Kadazan Dusun is one of around twelve members of the Dusunic Family of Languages. The Kadazan Dusun is the largest indigenous and largest overall ethnic group in Sabah. They are defined by their traditional geographical location in the Penampang District that encompasses part of the west coast of Sabah (Maps 1 \& 2). The Kadazan of Penampang traditionally relies on subsistence agriculture. They plant wet padi and other crops, including fruit trees, and vegetables. They also rear livestock, including chickens, pigs, and buffaloes. Within their community, they differentiate themselves according to location and topography such as the "Kadazan", the lowlanders (people living near the coast), "Tangaah", middle inhabitants, and "Potiang", the Highlanders. Notwithstanding the minor differences stemming from their geographical distribution, these groups shared various common myths, practices, beliefs, and language (Hussin \& John Baptist, 2015).
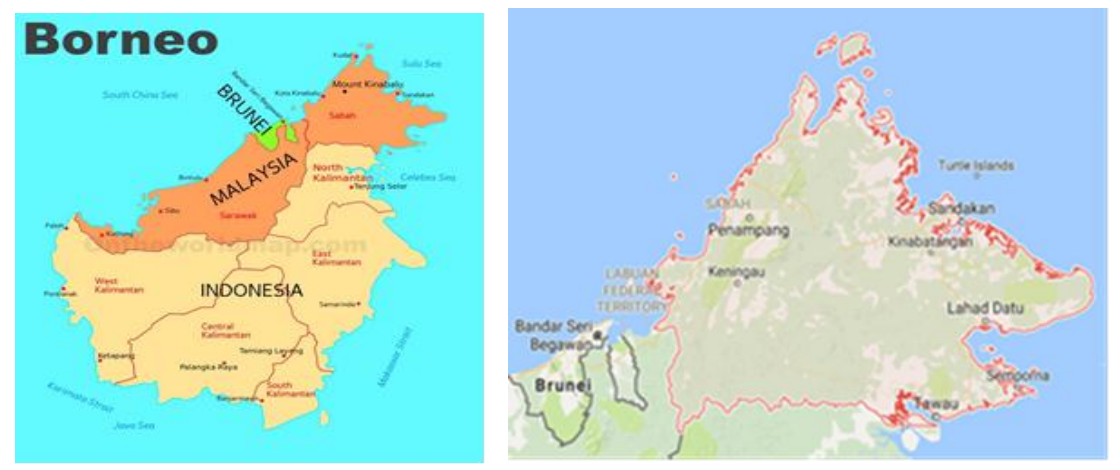

Maps 1 \& 2: Borneo Map (Source: “On the World Map" [n.d.]) and Sabah Map and locations of the District Headquarters in Penampang

(Source: “Discover Sabah" [2018].) 
The traditional Kadazan believed that the world they lived in is divided into spiritual world (pogun do hozob) and the physical world, and balance between the two parts ensured the continuity of the humans' welfare (Pugh-Kitingan, Hussin, \& John Baptist, 2011). For the coastal Kadazan, the two worlds had three realms: The upper realm or heaven (hibabou or diwato), the earth (hiniba), and the underworld or hell (dahom tanah) (Hussin, 2007a). The organisation of the spiritual universe was believed to be very complicated, in which human beings and spirits lived in the separate parallel worlds; both groups lived with families and offspring. The ideal relationship between the human and spirit worlds was one of balance or neutrality, described as being "cool" (osogit). According to the traditional belief system, any transgression by the human community or its members would cause an imbalance between the two worlds and produce trouble in the natural environment, which would further warm the earth making it hot (ahasu) the heated earth results in disasters and misfortunes such as sickness, infertility of livestock and unproductive lands. Thus, transgressions are avoided.

If the natural and social environment experiences calamities, the traditional Kadazan of Penampang would call bobohizan or priestesses to restore the order and balance between the worlds by performing rituals which were embedded with long poetic chants (inait), gong ensemble music, and dancing called sumazau. Bobohizan also helped the communities to fulfil other religious and moral obligations (Hussin \& John Baptist, 2015). Rituals which include sumazau dancing and gong ensemble music are traditionally performed to summon the spirits in the spiritual world to cure illness, to allow a good harvest (celebrated by both traditional feasts and modern harvest festivals), and are also performed in celebratory contexts such as the wedding ceremony.

The rhythm of the sumazau music is slow based on the beating of the six hanging gongs and single gandang drum in the ensemble called sompogogungan. The sumazau dance movement follows the beat of this sompogogungan. The sumazau consists of two basic dance motifs. In the first motif, the dancer steps from side to side, shifting weight from one foot to the other, while gently swinging the arms at the sides in time to the music. In the second motif, the dancer raises the heels slightly, with arms raised. For men, the arms are stretched out at shoulder level with hands moving up and down. For women, the arms are also outstretched, but at a lower level.

This sumazau style and the sompogogungan pieces of music are slower variants of the gong music and dance from the inland upland district of 
Tambunan in the interior, from where many of the coastal Kadazan originated many generations ago. The Kadazan Dusun gong ensemble or sopogandangan from Tambunan consists of a hand-held lap gong, seven hanging gongs and a drum or karatung. Its music, called tinondot, is much faster and more syncopated than that of the sompogogungan. The dancing in Tambunan, usually named magarang, is consequently faster. During the second motif, both men and women step up on their toes, and the women gently curve their arms from the elbows, with their fingers pointing upwards (Pugh-Kitingan, 2003; 2011, pp. 169-170)

This paper will discuss the sumazau soundscape and dancescape among the Kadazan of Penampang. Among the Kadazan, the spiritual world is highly significant and living in harmony with this world is extremely important for the longevity and survival of the communities. Hence, the musicscape and dancescape play vital roles in the cultures of communities and also in meeting their spiritual needs. Understanding the vital role of sumazau as a musicscape and dancescape in different social, cultural and religious dimensions, has gained little attention in the literature. In this paper, therefore, we would like to focus on different and interlinked dimensions of musicscape and dancescape of sumazau with the traditional rituals and contemporary events of the Kadazan and the wider Kadazan Dusun of Sabah related to sumazau and other dances. This is because sumazau and similar dances in related contexts are very important in sustaining the communities' identity.

\section{Literature Review}

The word scape refers to an extensive view or picture or representation of such a view as specified by the initial element where it is analogically a peduncle arising at or beneath the surface of the ground. In a cultural discourse, the scape is more than a physical interpretation. It is a combination of both tangible and intangible cultural aspects such as soundscape and dancescape (Hussin \& John Baptist, 2018). The word scape has been used in various contexts and dimensions in social, political, anthropological, sociological, political and other studies. These dimensions along with the suffix of scape include musicscape (Oakes (2000), dancescape (Szeto, 2010), sports-scape (Wheaton, 2004), heritage-scape (Di Giovine, 2009), social-scape (Albrow, (1997) and ideoscape, mediascape, technoscape, financescape and ethnoscape (Appadurai, 2000), servicescape, disease-scape (Harper and Armelagos, 2010) and lives-cape, moodscape and color-scape (Choy \& Ratnam, 2006)- a few to mention. 
Scape is often used in two contexts. Firstly, in the local context, the landscape or scape are local variables affecting the individuals in the given environment and circumstances (such as Oakes [2000], where the physical music environment is seen to be influencing customers and workers). Dance, music, and sounds are also used to link the seen with the unseen (spiritual) world through ritual performances (Blacking, 1985). At a given time, dance is product and process (Cowan, 1990) and associated ethnic and cultural identity and also a representation of the identity. Therefore, dance helps to understand the relationship between the social practices, ethnic groups and the strategies applied by the groups (Papakostas, 2015). However, when the dance is viewed as dancescape in a given time and space, it offers details of movement in the space, the interaction of bodies and soundscapes as these together move on the dance floor, transfer energy and emotions between the participants of the physical and unseen or spiritual world. Dance-scapes contains memories (the past) and ritualistic practices but hardly allow changing patterns of dance movement unless the social context has changed. Secondly, in the local-global context (Appadurai, 2006; Albrow, 1997; Smith, 1994), the scape is so big and full that it can include debates of transnational materials, ideologies, values, and cultures.

Oakes (2000) took the concept of musicscape from Bitner's (1992, cited in Oakes [2000]) model of the servicescape, in which musicscape is presented as one of the physical environmental conditions (scent, air, quality, and temperature) that affect customers' and employees' attitudes in the service environmental context. Bitner's model investigated a wider area of non-verbal communication within the service environment and presented how environmental aspects could influence the emotional and physiological responses of workers and customers. Oakes's (2000) musicscape visual model includes compositional tempo, harmony, volume and genre (classical, popular, and jazz); the composition of variables in the model could include liking of the customers (Oakes \& North, 2008). Porteous and Mastin (1985, p. 169) defined soundscape as "the overall sonic environment of an area, from a room to a region". Schulte-Fortkamp and Kang (2013) defined soundscape as "an environment of sound with an emphasis on the way it is perceived an understood by the individual, or by a society". In other words, it could also be considered a combination of sounds that come from an environment. Johnson (2011) defined dancescape as a collection of dance pieces that are interconnected through different ways that include membership networks, geographic nearness, or influence. Moreover, also connected through the past and the future (John Baptist \& Regis, 2012; Pugh-Kitingan, 2017). 
The concepts of musicscape and dancescape are also applied in transnational, transcultural and fluid contexts (as Appadurai [2006] has envisaged) as well as in the static context with the local communities' practices and rituals. In research, the dancescape and musicscape are often applied and discussed separately. However, dancescape and musicscape among some traditional communities, such as the Sama-Bajau (Hussin \& John Baptist, 2018) and the Kadazan, are often part and parcel of the same phenomenon. In dancescape, bodies, knowledge, expertise, and ideas flow in continuum and also keep changing.

Among Sabah's indigenous cultures, the various rituals determine contexts and processes whereby human beings can interact with and appease spiritual beings so that life will always be balanced. The relationship between man and spirits in the spiritual world should always be balanced or neutral, taking into account every action taken in the real world because it will affect the spiritual world. Hence, the rice planting activity is not merely to provide food to eat, but is also to enrich the spirits in the spiritual world (Hussin \& Santamaria, 2008; Hussin \& Santamaria, 2012).

Among the Kadazan of Penampang, it is believed that the relationship between the rice spirit or life force of the rice, the bambaazon, and other spirits must always be good or cold (osogit) otherwise the relationship is said to be hot (ahasu). Hence, each process in the ritual while planting rice is to give respect to the bambaazon and the other spirits, particularly the house guardian spirit, the miontong. It is believed that the correctly performed ritual will always ensure balance and will protect the humans from various sickness and disasters as well ensuring that the rice plants will grow abundantly and will produce good yields.

The monogit ritual series of the Penampang Kadazan traditionally takes place during the rice planting season. It is usually done once in two or three years or when there is adversity or sickness in the community. The ritual must be done to make sure that the house guardian spirit (miontong) is at peace so that it will put things back the way they were. The ritual was traditionally done over four days and three nights conducted by female ritual specialists known in the Coastal Kadazan dialect as bobohizan headed by their leader, the bohungkitas. 


\section{Methodology}

This paper is based on research conducted from 2001 until 2018 on the community of Kadazan of Penampang and Sabah community who were involved in Sumazau performances.

The research began with the literature review based on the past research and publication on the ritual of Kadazan of Penampang, rice farming and harvest festival also music and dance performances related to sumazau. Observations followed it. Moreover, participant observations were used in two monogit rituals conducted in 2001 and 2004 at few villages in Penampang, Sabah. The interviews were conducted with the practitioners of the ritual especially the priestesses, called bohohizan who are led by their chief bobohizan called bohongkitas. Interviews were conducted to tap the information and local knowledge from the local experts especially the ritual practitioners. Rituals, sumazau dancing was filmed, and music of the sompogogungan ensemble was also filmed and transcribed Observations, and interviews also conducted with a few sumazau practitioners, musicians, dancers and cultural organisers that appreciate sumazau for their creative work in the creative industry.

\section{Results and Discussion}

The Rituals of the Kadazan--Enriching the Soundscape and Dancescape of Sabah

\section{Rice farming ritual}

Before Malaysia's formation in 1963, the Kadazan planted rice and other plants for their consumption and survival. Their life's routine also depended on the cosmological order and organisation. At each stage of the rice planting or farming, rituals were performed by the Kadazan priestesses. They believed that the rice spirit was present in the physical world and it had a connection with the other spirits. The ritual was the implementation of the ancestral myth (concerning the pampang or primaeval stone from which the Creator and his wife emerged before they created the world) and belief in the rice spirits. The practice of the ritual was performed by a bobohizan who played an important role to transfer the myth and its practical knowledge to the next generation. The myth was a source of the ancient Kadazan belief in Kinoingan (lit. "Supreme God"), his wife or Suminundu ("the miraculous one") and their daughter Poninzuvung/Izoton as the spirits. Through this mythology, the 
Kadazan explained the origin of the cosmos, the heavens, their cosmology, and the belief system of their community. In the myth, Poninzuvung was sacrificed to be the source of food (rice plants). The primary food plant was rice that grew from the flesh of Poninzuvung. Therefore, her spirit was considered the rice spirit and known as the bambaazon. This myth about the supreme spirits had a significant effect on the Kadazan way of life that included their thinking and an entire way of living. The community and its adat or customary norms worked as a guard through four institutions namely the Village Head (Huguan Pogun), the Village Council (Sinompu'uvan Komohoingan), religious advisers, (Sinompu'uvan Bobohizan) and warriors (Sinompu'uvan Pangazou).

Actions in the real world affected the spiritual world. Therefore, the rice planting ritual was not only to provide food but enrich the spirits in the spiritual world. It also means that the relationship between the spirits and the bambaazon should always be good or cold (osogit). In the opposite case, the social and natural environment would become hot (ahasu) and very unpleasant. In the ritual process of planting rice, respect is given to Poninzuvung and other spirits, particularly the house guardian spirit, the miontong. The outcome included the protection of the community members from disasters and sickness and ensured the abundance of the rice plants. The monogit ritual thus traditionally took place during the rice planting season. If calamity affects the community, it would be done twice or thrice a year to ensure that the house guardian spirit (miontong) is at peace and will put things back the way these were.

\section{Sumazau music and dance in the Monogit-balancing the hot and cool of the Kadazan world}

Monogit, part of traditional rice farming of the Kadazan of Penampang used to be held bi-annually. The process of performing the rituals started with a single household and continued from one household to another throughout the village; it also depended on the availability of the bobohizan. In the ritual performance, the sacrifice of the pigs at least two years old was mandatory. It is traditionally performed over four days and three nights. The beating of the drum (gandang) (Figure 1) leading the music played by the ensemble called sompogogungan (comprising six gongs) (Figure 2) and the sumazau dance are essential parts of the ceremony. 

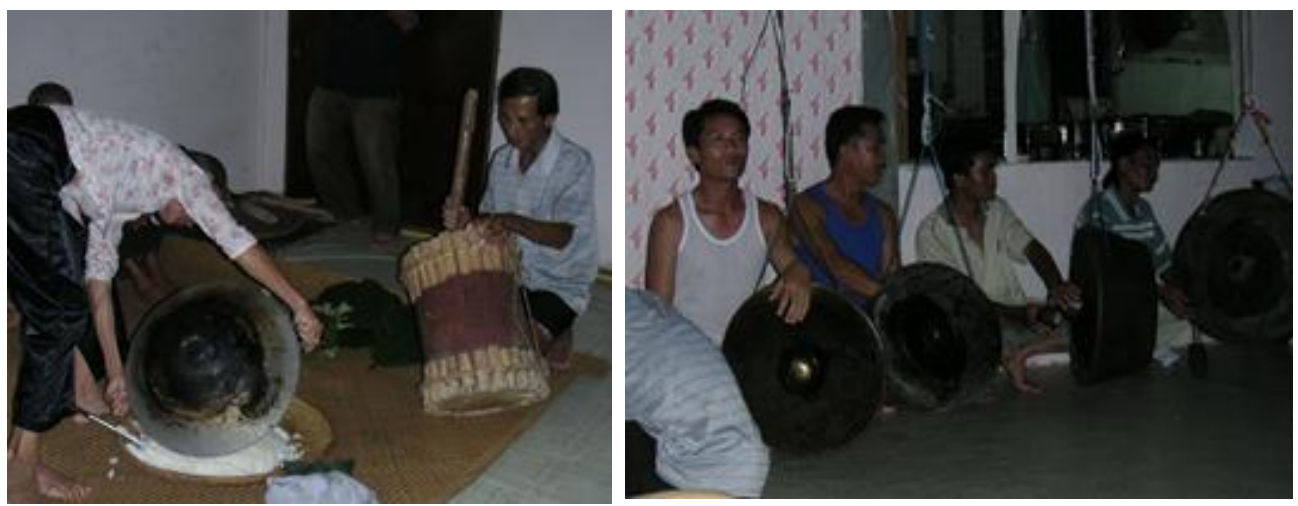

Figure 1 (left) Drum@gandang in the monogit ritual and Figure 2 (right), the sompogogungan ensemble accompanying the whole process of monogit ritual (Source: Hanafi Hussin)

The gandang beating and the composite sound of the gongs in the sompogogungan in the ritual context are believed to connect man with the spiritual world. The gandang beating is periodically done by a bobohizan at various stages in the ceremony while reciting an inait. The sound of the gandang and the sompogogungan is believed to assist the bobohizan in entering the spiritual world to meet, stir, and awaken the evil spirits to ask them to return the trapped human spirits.

The first gandang beating or mamason takes place around $7.00 \mathrm{pm}$. This particular gong beating is done by the father of the conjugal family who is organising the monogit and marks the beginning or the kotudungan, the first night. It awakens and invites the spirits in the upper world to join the event. Other rituals by the bobohizan with the drum include matang (awakening the spirits in the spiritual world and also the spirits of the ritual objects), tumingak (raising and empowering the spirits), and savak (calling back the spirits who left). While these sessions with the gandang take place, food offerings or pamanta are prepared, especially fermented rice beer (tapai). These are placed in the part of the ritual space, together with antique clothing for the miontong, including a traditional male headcloth, jacket and coin belt.

Communication and negotiation with the spirits then continue in the special trance session called modsuut when each of the bobohizan is believed to enter different parts of the spiritual world. This takes place from 1.00 a.m until up to 5.00 am. Pamanta preparation continues on the second day which is called mamasa'an or "feeding the spirits". After a live, bound, the sacrificial pig is brought into the house and laid in the ritual space, more gandang beating and recitation of inait by bobohizan-called mihung (calling the spirits to come near) and sumonson (invitation to enjoy the prepared dish) takes place. 


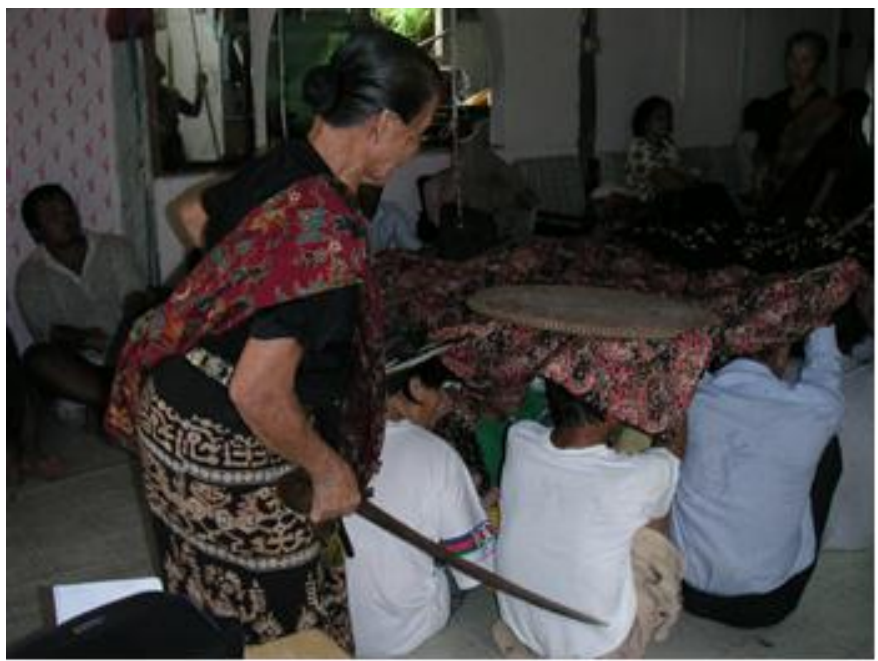

Figure 3: Performing sumazau in magampa as part of the healing process in the monogit (Source: Hanafi Hussin.)

The pamanta offerings are also made following a process and sequences, while the bobohizan accompanied by the sompogogungan dance the sumazau in a unique manner including dancing around a group of family members sitting under blankets who suffer from bad dreams, migraine and other minor illnesses (magampa) (Figure 3), dancing with palm fronts and swords during feast presentation for the spirits (mundang), inviting the miontong to dance and serving of the dishes (pasasazau do miontong), sending back some of the spirits (hoputan), and grouping the spirits that are left (monoinig).

During the pasasazau do miontong, the bobohizan doing the sumazau is in a trance and possessed (nosuang) by the miontong when her body movements become unusually very strong and full of energy. She will eat chicken, drink tapai and throw rice where the spirits are believed to line up in front of the sacrificial pig. At this time all the good and evil spirits are believed to be being invited to partake of the food by the miontong, which is the highlight of the ritual. This stage of the ritual dance is the peak and most significant point. Here, the beating of gandang (drum) from the sompogogungan and the sumazau dance have become highly essential tools in the monogit. The combination of both elements work in two ways: It is believed that the traditional Kadazan Penampang music and dance performance and also a healing ritual because it is believed to rid the house of evil spirits. 
The third day is called kinapangasan (the climax of the series) which begins with another modsuut trance session, to meet with the spirits in the spiritual world in the early morning to send back the offerings and spirits, and to bring home any last remaining stolen household spirits and rice spirits. No drumming, gong music or dancing is performed. Later in the late morning, another pig is sacrificed. The whole monogit traditionally ends on the next day (the fourth day) in the fourth phase or Pa'atod Hangod, an appeal to the dudui or guardian spirits in the paddy field with offerings and requests to safeguard the rice field (Figures $4 \& 5$ ).
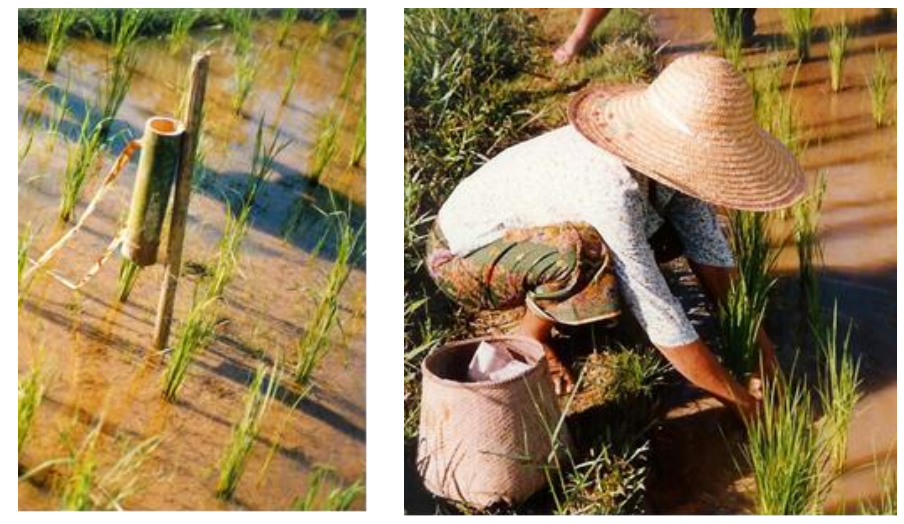

Figure 4 (left) Rice farm and Figure 5 (right) performing the sacred pa'atod hangod sending an offering to the guardian spirits of the rice field (Source: Hanafi Hussin.)

\section{Sumazau Music as a Sacred Soundscape of the Kadazan}

The sumazau music is collectively played using six hanging gongs in the sompogogunan ensemble, with the gandang drum (Figure 6). Sompogogungan playing the sumazau gong ensemble music accompanies the monogit ritual process, which bridges the human and the spiritual worlds. It is believed that the beating of the gandang and the sound of the sompogogungan play the role of connection with the spirit world. The bobohizan have a special power of connecting to the unseen world on the beat and rhythm of the music through their dancing. The recitation of inait to the spiritual world, as well as the music and dance stir and awaken the evil spirits to return the trapped subsidiary human spirits and rice spirits. 

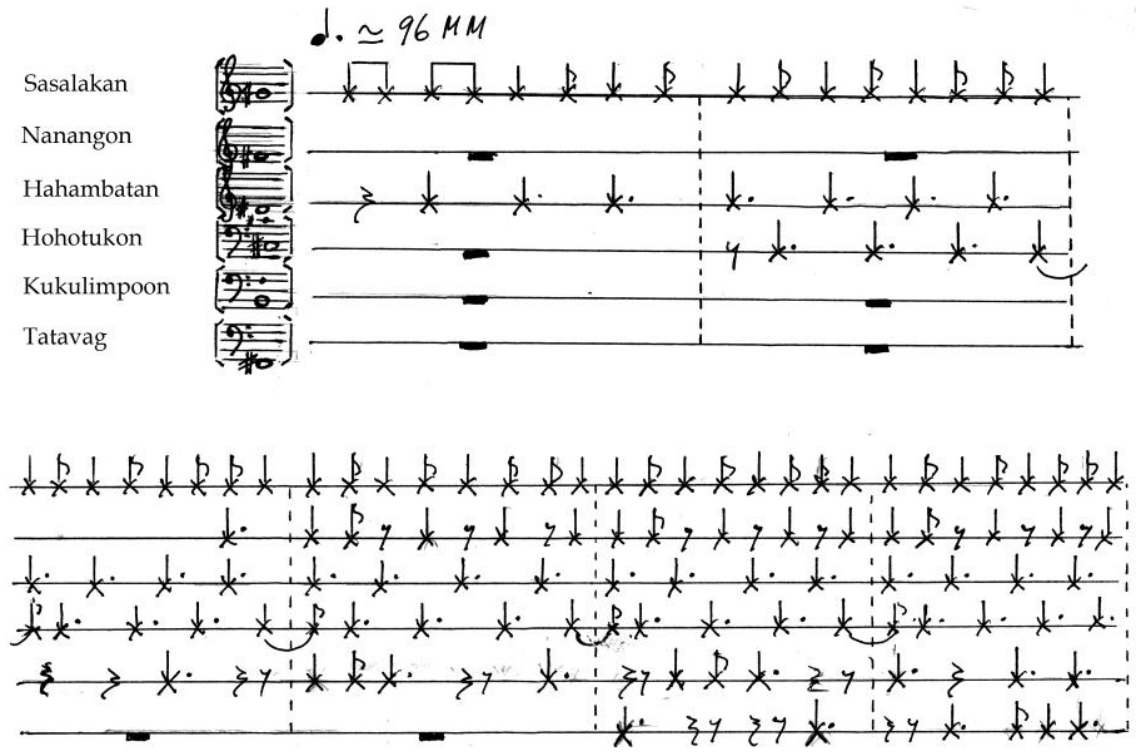

\section{Figure 6: Music of the Kadazan sompogogungan gong ensemble from} Penampang (Source: Pugh-Kitingan, Hussin, \& John Baptist [2011, p. 144].)

As observed by Pugh-Kitingan $(2012,2018)$ among the Dusun Tinagas of the upper Sugut River in northern Ranau District, traditional gong ensemble dance and music are contextualised as per the audiences, which could be human and non-human (spirits). Although Dusun Tinagas music and dance are very different from those of the Penampang Kadazan, this observation also applies to the sumazau. In the human contexts, gong ensemble music and dance in non-religious group performances are an expression of happiness and social harmony. In the ritual contexts, the non-human audiences are not only the spectators but in some cases are believed to participate in the events through dancing freely and partaking of food offerings and sacrifices. In some ritual contexts, even the Creator, as well as other good and wicked spirits are believed to be present.

To connect the two worlds in traditional Dusunic ceremonies, ritual specialists or priestesses play the role of mediators. They recite sacred inait or long ritual poetry, perform rituals and offer blood sacrifices at different events to ensure a balance between the seen and unseen worlds. Priestesses also attempt to connect the two worlds through dancing to the rhythm of gong ensemble music. In the ritual contexts, the spirits participate in the dance in two ways, either by possessing the priestesses or by symbolic representation. 
The importance of gong ensemble music as a bridge between the seen and unseen worlds is recognised in various other cultures, apart from the Penampang Kadazan (Pugh-Kitingan, Hussin, \& John Baptist, 2011; PughKitingan, 2012, p. 2014).

In these contexts, the dance is created upon ensemble gong music, which in a symbolic context, shows actions, interactions and communications taking place in the unseen world. Dance is a practical or physical exercise as well as learning for the audiences, but its physical existence is possible only through the gong music. In a purely ritualistic context, only the expert musicians can play the ensemble gong music, as they follow the requirements of the sacred ritual poetry chanted by the priestesses (Pugh-Kitingan, 2012, 2014, 2018).

\section{Sumazau dance as a sacred dancescape of the Kadazan}

The sumazau dance sequences on the second day of the monogit are known as sumazau magampa, mundang, and pasasazau do miontong. In symbolic terms, these dances help to clean impurities and cure sicknesses. At the time of dance by the dancers, offerings (pamanta) of rice and rice wine are made to the spirits. The pamanta is offered in sequence and process. As mentioned above, the bobohizan specially perform the sumazau- each in a sequence. During pasasazau do miontong a bobohizan willactually become possessed by the miontong. Sumazau in the monogit is thus a means of communication and forming transactions with the spirit world on behalf of the family organising the ceremony. Through dance, the bobohizan directly interact with the spirit world and act out their transactions with the spirits.

\section{Contemporary Scape of Sumazau--Living Sumazau Music and Dance}

Rice planting activities no longer require blessings from any spirits, and once in a while, rice agriculture has experienced loss due to external factors such as climate change or the introduction of new rice varieties. Farmers no longer believe that the rice fields are looked after by the spirits. Rice cultivation has been taken over by the use of modern technology such as fertilisers and pesticides. Science and technology have also brought changes as to how to work the rice fields. The society no longer needs to work together in the traditional labour exchange (mitatabang) to prepare the rice fields which have been taken over by modern and sophisticated machines. Innovations have also changed the pattern of how the land is used, and the Penampang Plains landscape is no longer an agricultural area. Currently, the landscape has become filled with infrastructures such as housing, schools, churches, and 
mosques. Farming areas are now economic and commercial centres. Most of the coastal plains of Penampang are not agricultural land any more; the area has become a commercial centre, and its people are not rice producers, but consumers.

In social contexts, sumazau dancing is often performed by pairs of male and female dancers, who lead the way during the dance if other participants wish to perform in the dance. Sumazau dance works as a customary way of life or adat which maintains various traditional aspects of life that included religion and language.

Sumazau dance and music is taught to school-aged girls and boys so that they continue with the tradition and pass it on to the next generation. In Kadazan villages, besides, classes of Kadazan traditional dance are organised for children to prepare them for the contemporary annual harvest festival (Barlocco, 2010). The Kadazan of Penampang is proud of sumazau music and dance, for which they are renowned throughout Sabah. In olden times, sumazau was primarily used in religious rituals, which also included a triumphant return from head-hunting, but was also used in celebratory contexts such as weddings and moginakan family feasting where ordinary people danced sumazau to the sompogungan music.

The sumazau classes for children are often held in the middle of villages at the community hall (Malay: balai raya), where senior local teachers voluntarily teach the students. Three months before the annual festival, the sessions are held on a regular basis almost every afternoon. The dance learning includes movements with stretched out arms, and the 'war cry' (pangkis) as a form of cueing, characteristics, which make an important example of the formation of ethnicity's basic socialisation (Jenkins, 2008;). It is not only the learning of the dance but the learning of Kadazanness. Children acquire the social, cultural, religious and political Kadazan habitus, which is inscribed into children's mind and bodies. The dance and music are the primary sources of socialisation, which is important for understanding the difference between us and others, and also essential for providing a sense of self-identity (Bentley, 1987; Jenkins, 2008). This socialisation process gives them "a deep sense of belonging and oneness with those sharing similar early life experiences." In this case, the children learn physically, through their bodies, to be Kadazan by moving as Kadazan, by acquiring physical skills that not only make them able to court a suitable partner properly but also unequivocally express their Kadazan identity and distinguish them from outsiders" (Barlocco, 2010, p. 417). 
In the contextual interaction between ensemble sumazau music and dance, three gazes are observed at different levels or by different spectators. At the practical and auditory level, the gong music is seen through the gaze of the musicians (experts in playing the gongs). The dance experts' gaze as they move according to the specific sounds of the gong beats. The gaze of both human and non-human audiences who comprehend the underlying social, cultural and religious meanings expressed through the specific dancescapes (movements, steps, styles, angles) and musicscapes (high and low pitch of the music and slow and fast beats and rhythms). These meanings are infused into the minds of the Kadazan since their childhood.

This interaction has been observed in many other cultures in Sabah. Among other Kadazan Dusun communities and indeed among other Dusunic ethnic groups, there are many different varieties of gong sets, styles and patterns of music, and dance performances. In many of these indigenous communities, large ensembles of hanging gongs produce a total composite texture of colotomic patterns within the gong music, which informs which enlightens the movements of the dancers at the time of dancing (PughKitingan, 2003, 2012, 2018). In other communities where the kulintangan is played together with hanging gongs, such as coastal communities and interior communities with river access to the coast, the melodic motifs of the kulintangan are of primary importance, with the hanging gongs playing a supporting role (Pugh-Kitingan \& John Baptist, 2005). Dancers in these places tend to listen to the music of the kulintangan, but still, move their feet according to the rhythm of the hanging gongs. At another level, dancing among indigenous societies in Sabah can reflect social relationships, especially gender balance and the principal role of women who, in the past, were the traditional ritual experts.

Moreover, it can also illustrate the egalitarian nature of social life especially from solidarity point of view. Traditional gong music and dance in both ritual and social contexts can reflect the idea of a stable and balanced universe (the physical environment and spiritual world) where humans to live in proper relationships with each other and in accordance to the traditional norms established by the Creator. The movement of dance, which is the visual manifestation of the gong ensemble music, indicates the balance and order between the unseen spiritual world and the seen world of human beings. In many communities, this aspect of dance as a reflection of social and spiritual balance continues into new contexts, including church celebrations (PughKitingan, 2012 and 2016). 


\section{Highlighting and Contemporizing the Sumazau Tune and Movement}

The contemporary Kadazan Dusun are somewhat different from their forefathers, who used to perform rituals along with dance and music to appease spirits. Today, the Kadazan Dusun worldview has adapted and changed given the modern world and its impact on their life routines (Hussin, 2007b). They no more believe that the spirits take care of rice fields because fertilisers and pesticides can perform these tasks for farmers still cultivating lands in Penampang (Hussin, 2008). New technology has changed the agricultural lifestyle to modern patterns of life. Today, most of the rice fields on the Penampang Plains have turned into idle lands or locations for housing estates.

Moreover, Penampang Kadazan, as part of the Kadazan Dusun ethnic majority, now share their territory with various other ethnic groups. Changes in their worldview, lifestyle and practices also mean transformation in their economic, social, and political aspects, which have pressed them to search for their genuine identity, and they attempt to spark their spirit of indigenous nationalism. The Penampang Kadazan have adapted rice farming ritual elements through festivities or new staged rituals events, in particular during the State Level the Harvest Festival or Kaamatan. For the coastal Kadazan, the former rice farming ritual is now a commoditised symbol of identity, which they perform onstage during the Harvest Festival but in practice, they no longer practice rice cultivation (Hussin, 2008).

The Kaamatan has undergone many changes and developments from being a family and village level feast at the end of harvesting (as it still is in most interior Kadazan Dusun areas), to being an officially recognised Harvest Festival holiday for all indigenous Dusunic, Murutic and Paitanic rice-planting societies, as during the 1950s and for all of North Borneo from the 1960s under the British colonial government (before Malaysia's birth in 1963), to becoming a distinct statement of indigenous cultural identity as it is today. From the early years, the Harvest Festival included many elements that continue today such as special church services, traditional sports, traditional music and dancing, traditional feasting, symbolic rituals and stage enactments of rice cultivation, and parades of best costumes that, since 1960, have developed into a cultural beauty pageant (formerly Miss Harvest Festival, today Unduk Ngadau). Today, the Kaamatan is celebrated at the family, village, district, state, and national levels for all Sabahans (Hussin 2008). 
A pivotal development in the Harvest Festival as an expression of indigenous identity occurred in 1982, when Tan Sri Datuk Seri Panglima Joseph Pairin Kitingan (then Datuk), President of the Kadazan Dusun Cultural Association (KDCA, then KCA) and now the Huguan Siou a warrior for the rights of indigenous Sabahans, organised the true state level Harvest Festival in 1982 on grazing land in his village of $\mathrm{Kg}$. Karanaan, Tambunan. This was in response to the official Harvest Festival organised by the Berjaya State Government in Keningau, a few weeks beforehand, from which all indigenous people were barred, and native cultural elements were excluded.

In ensuing years at these celebrations, ideological and political differences were kept aside to promote unity. The Kaamatan played a central role in the reinforcing the Dusunic identities. The inclusion of coastal Kadazan traditions at the State Level festival such as segments from the Penampang magavau ritual, sompogogungan music, sumazau dance, and others, led them to become icons of Penampang Kadazan identity. These segments together gave prominence outside of the Kaamatan to indigenous expression as a representation of Sabah indigenous identity and culture for the general public. Indirectly, the post-harvest magavau ritual and the Penampang sumazau music and dance for many years served as the dominant cultural identity and that Kaamatan festival at the State Level to promote and strengthen Kadazan identity. All these elements helped to unite different groups in Sabah. Therefore, in this context, the rice and its celebration as a festival was considered as a powerful tool to unify the groups in Sabah (Hussin, 2008).

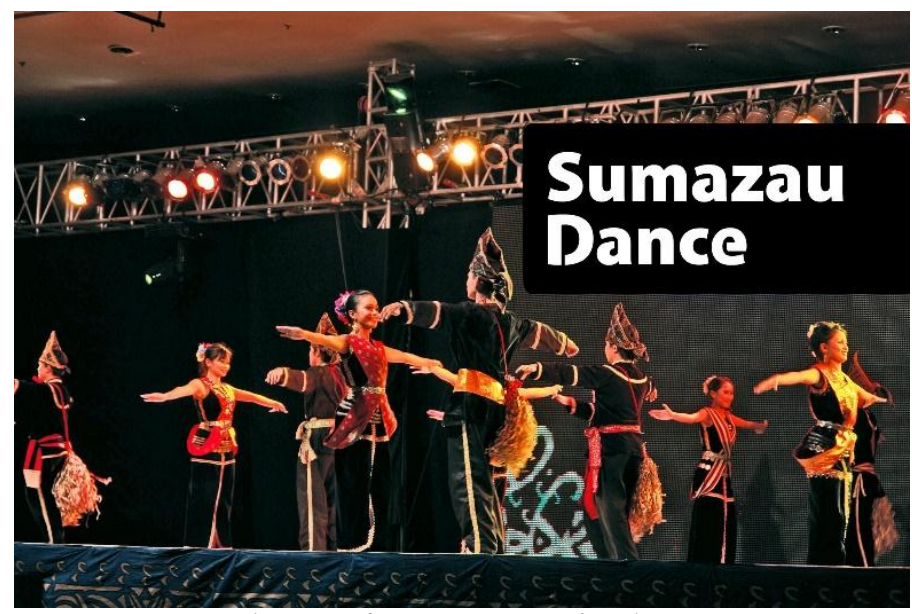

Figure 7: Sumazau dance of Penampang in the contemporary setting - as a stage performance and also as the backup dance for a popular song with sumazau beat (Source: Sumazau-The Kadazandusun dance [n.d.].) 


\section{Heritagizing the Sumazau as Sabahan and Malaysian Heritage}

Although the sumazau dance was a part of the monogit ritual, it is now choreographed for various events including concerts for tourists, church services, various staged festivals and other gatherings. Therefore, sumazau has become a living Kadazan heritage. Sumazau music is no more ritualistic music but has become a part of popular music, and is often used as an accompaniment to songs. Generally, sumazau is considered the state of Sabah's dance.

It continues to be performed during harvest festivals as a thanksgiving for a bountiful harvest, and at wedding celebrations, as in traditional contexts. In contemporary times, sumazau music and dance have become an iconic scape of Sabahans and Malaysians. The sumazau musicscapes and dancescapes are nowadays often combined with other traditional and modern materials (tools and tunes) and sung in songs and performed in multiple ways. Today, markets are crowded with CDs of modern pop songs using the melodies and rhythms of sumazau beats, in which the listener can quickly identify the use of traditional gongs, together with the use of the modern electronic instruments. Simultaneously, the sumazau traditional dancescapes now also follow the modern recorded music, where they follow gong based ensemble music played on modern musical instruments. Various popular songs using modern sumazau music beats are available on CDs and online videos (Hussin, 2008).

The modernisation of sumazau music and dancescapes has also angered the older community members, who claimed that outsiders were now performing their traditional roles and practices, and such things are offensive to the community members. They also complained that the outsiders performed the sumazau dance in a distorted manner because they did not use the required number of musical instruments and dancers (Tay, Hussin, Khaw, Mohd. Anis Md. Nor, \& Bulan, 2010).

In order to preserve the cultural practices and costumes of the Penampang Kadazan community, the federal and state governments have declared the sumazau dance and its music, and the traditional costumes as a national heritage under the law (National Heritage Act, 2005, the Sabah Cultural Heritage (Conservation) Enactment, 1997, and the Copyright Act, 1987). The list of protected objects and practices includes ritual processes and tools, such as the bobohizan's ritual paraphernalia, offering dishes (pamanta) to serve food, traditional drinks, ornate clothing, musical instruments (gong and gandang ensemble) and the sumazau dance. These objects are classified as the Kadazan tangible cultural heritage, while the sompogogunan music and the 
sumazau dance are classified as an intangible cultural heritage that reflects the fundamental identity of the Penampang Kadazan (Hussin, 2008).

\section{Conclusion}

The preceding reviewed and analysed sumazau performances as dancescapes and musicscapes performed by priestesses and dancers on different occasions. In traditional contexts, these scapes were meant to connect and balance the spiritual and physical worlds. The soundscape and dancescape constituted the desired environment in which physical actors summoned spiritual entities, who were met, invited to eat fresh food, and were amused or overpowered in cases where some of these had become harmful to the community or its members.

In the ritual context, the dancers performed unique dancescapes on the sound/musicscape. All the actors and audiences knew the context (Smith, 1994) of the two scapes coherently interacting in the ritual performance. The soundscape and dancescape worked together to guide the audience as to how to maintain the relationship with the spiritual world and how to live life the physical world without sinning that had often invited anger of spirits. Music from the drum and gong ensemble combined with sounds from footsteps (dancescapes) to create melody and rhythms that represented (or symbolised) the unseen world. These melodic and rhythmic structures had to be performed in the physical world through specific body and foot movements so that ties with the spiritual world could be strengthened.

Beyond this traditional role of dancescapes and musicscape, ritual performance is subject to outside influences and change. Appadurai (2006) envisaged that nothing is permanent or remains in the same state, but everything is changing. This is partly due to modern factors, which have influenced the communities, and somehow diminished their traditional dance and music scapes through the introduction of modern tools and instruments, and through interventions. Although the government has listed the Penampang Kadazan dancescapes and musicscapes in the list of tangible and intangible cultural heritage through law, the authenticity of the dancescapes and musicscape of the community has dramatically declined. Still, these scapes are cherished as the identity of the community and also as a great source of balancing the power between the seen and unseen worlds.

Among the various Dusunic ethnic communities in the state of Sabah, the Penampang Kadazan are often presented in the media as the most 
dominant community in the aspects of lifestyle. Affinity and cultural evolution which influence rituals and the management of old traditions and the building of identity through the Kaamatan clearly show their dominance and effectiveness. This matter which makes the community proud and has resulted in the construction of the Hongkod Koisaan ("Unity Centre" that comprises a concert hall, KDCA offices, and the Koisaan Cultural Village of traditional houses) which is in Penampang and has become a landmark for the Kadazan Dusun community's success and pride. Among members of the Kadazan Dusun Cultural Association are those of the Kadazan community of Penampang.

The sumazau dance and music of Penampang are accepted and recognised, not only as communal dancing and music of the Kadazan community but is performed within the state level Kaamatan and other various state gatherings. The musical influence of the Penampang sumazau and sompogogungan have also affected the development of popular Kadazandusun music and songs. Many of the popular songs composed by Kadazan Dusun composers and musicians, the majority of whom come from Tambunan, follow the beat and rhythm of the Penampang sumazau. It is clear that the expression of their identity through music and dance is very flexible and can be changed spontaneously according to place, situation, and context. Although the showcasing of the community's identity may change dynamically, it is clear that the culture of the Kadazan community on the Penampang Plains has directly played an essential role in making the Kadazan Dusun of Sabah as a community known and respected not only at the state and national levels but also internationally as well.

\section{Acknowledgement}

The authors would like to thank and acknowledge and acknowledge the financial support provided by University of Malaya under the Research Clusters Sustainable Science (SUS) and Humanities and Ethics (HNE) for the research grants ER025-2012A, RP005D-13HNE \& RP001A-13SUS. The authors also acknowledge the contributions made by the research participants who patiently took part in this study. This study would not be possible without all of their assistance. 


\section{References}

Albrow, M. (1997). Travelling beyond Local Cultures: Socioscapes in a Global City. In J. Eade (Ed.), Living the Global City: Globalization as a Local Process (pp. 35-52.) London: Routledge.

Appadurai, A. (2006). Disjuncture and difference in the global cultural economy. In M. G. Durham, \& D. M. Kellner (Eds.), Media and Cultural Studies: KeyWorks (pp. 584-603). Malden: Blackwell Publishing.

Barlocco, F. (2010). The village as a 'community of practice': Constitution of village belonging through leisure sociality. Bijdragen tot de taal-, land-en volkenkundelJournal of the Humanities and Social Sciences of Southeast Asia, 166(4), 404-425.

Bentley, G. C. (1987). Ethnicity and practice. Comparative Studies in Society and History, 29, 24-55.

Blacking, J. (1985). Movement, dance, music and the Venda girls' initiation cycle. Society and the Dance: the social anthropology of process and performance, 64-91.

Choy, S.-L., \& Ratnam, A. (2006, October 29). Chosen by the goddess. The Star. Retrieved from https://www.thestar.com.my/data/archives/2013/07/02/16/46/chosen-bythe-goddess/

Cowan, J. K. (1990) Dance and the Body Politic in Northern Greece. Princeton: Princeton University Press.

Di Giovine, M.A. (2009). The Heritage-scape: UNESCO, World Heritage and Tourism. Lanham: Lexington Books.

Discover Sabah. (2018). KK Leisure Tour \& Rent A Car's website. Retrieved from http://sabahtour.kkleisure.com/discover-sabah/

Hussin, H., \& Santamaria, M. C. M. (2008). Dancing with the Ghost: Experiencing the Pagkanduli Ritual of Sama Dilaut (Bajau Laut) in Sikulan, Tawi-Tawi, Southern, Philippines. JATI - Journal of Southeast Asian Studies), 13, 159-172.

Hussin, H., \& Santamaria, M. C. M. (2012). Celebrating with the Lord of the Sea (Tuan Laut): The Pagkanduli of the Sama Dilaut of Sitangkai, Tawi-Tawi, Southern Philippines. In H. Hussin, \& M. C. M. Santamaria (Eds.), Sama Celebrations: Ritual, Music and Dance of Sama Dilaut and Sama Bajau in Southern Philippines and North Borneo (pp. 9-22). Kuala Lumpur: University of Malaya Press.

Harper, K., \& G. Armelagos. (2010). The Changing Disease-scape in the Third Epidemiological Transition. International Journal of Environmental Research and Public Health, 7(2), 675-697. 
Hussin, H. (2007a). Ritual, Identity and Changes in the West Coast of Sabah: The Experience of the Kadazan Penampang Community. JATI-Journal of Southeast Asian Studies, 12, 189-210.

Hussin, H. (2007b). Worldview dan Amalan: Pengalaman Kadazan Dataran Penampang. Borneo Research Journal, 1, 7-29.

Hussin, H. (2008). Performing Rice Farming Rituals by Penampang Kadazan of East Malaysia: Between Sacred Ritual and Secular Performance. JATIJournal of Southeast Asian Studies, 13, 173-190.

Hussin, H., \& John Baptist, J. (2015). Death and Rites among the Kadazan Penampang of Sabah, Borneo, Malaysia. Borneo Research Journal, 9, 6785.

Hussin, H., \& John Baptist, J. (2018). Scaping The Bajau Through Rituals and Celebrations in Maritime of Malaysia and the Philippines. Paper presented at the International Conference on Bajau (ICONBAJAU) 2018, Semporna, Sabah, 18-22 April.

Jenkins, R. (2008). Rethinking ethnicity: Arguments and explorations (2nd ed.). London: SAGE.

John Baptist, J., \& Regis, P. (2012). Magpa-igal Jin: A Ritual Dance, Linking the Past with the Present among the Sama Dilaut of Sabah. In B. Abel, H. Hussin, \& M. Santamaria (Eds.), Oceans of Sound: Sama Dilaut Performing Arts. Hildesheim: OLMS.

Maori Yvana. (2015). Introduction: Sabah's Largest Tribe - Kadazandusun. Retrieved 11 June 2018, from http://maoriyvana.blogspot.com/2015/04/sabah-largest-tribekadazandusun.html

Oakes, S. (2000). The influence of the musicscape within service environments. Journal of services marketing, 14(7), 539-556.

Oakes, S., \& North, A. C. (2008). Reviewing congruity effects in the service environment musicscape. International Journal of Service Industry Management, 19(1), 63-82.

On the World Map. (n.d.). Administrative divisions map of Borneo. Retrieved from

http://ontheworldmap.com/indonesia/islands/borneo/administrativedivisions-map-of-borneo.html

Papakostas, C. (2015). Dancescapes of Dionysus. In A. Shay, \& B. SellersYoung (Eds.), The Oxford Handbook of Dance and Ethnicity (pp. 563-584). Oxford: Oxford University Press. DOI: 10.1093/oxfordhb/9780199754281.013.35. 
Porteous, J. D., \& J. F. Mastin. (1985). Soundscape. Journal of Architectural and Planning Research, 2(3), 169-186.

Pugh-Kitingan, J. (2003). Alat-Alat Muzik dan Muzik Instrumental Kadazandusun Tambunan. Kota Kinabalu: Pejabat Kebudayaan dan Kesenian Negeri Sabah.

Pugh-Kitingan, J. (2011). Dance and Ritual in Sabah. In Mohd Anis Md Nor, \& Stephanie Burridge (Eds.). Sharing Identities: Celebrating Dance in Malaysia. (Volume 3 in Series Celebrating Dance in Asia and the Pacific (pp. 166-186). New Delhi: Routledge.

Pugh-Kitingan, J. (2012). Gong Ensemble Music of the Dusun Tinagas of Sabah through the Gaze of Movement. Yearbook for Traditional Music, 44, 149165.

Pugh-Kitingan, J. (2014). Balancing the Human and Spirit Worlds: Ritual, Music and Dance among Dusunic Societies in Sabah. Yearbook for Traditional Music, 46,170-190.

Pugh-Kitingan, J. (2017). Connecting the Cultural Past with the Future: Contextualising Dance and Music Traditions into Christian Worship among the Dusun Tinagas of Sabah, Malaysia. In P. Matusky, W. Quintero, Tan S. B., J. Pugh-Kitingan, D. Quintero, \& C. Y.-M. Yong (Eds.), Proceedings of the $4^{\text {th }}$ Symposium: The ICTM Study Group on Performing Arts of Southeast Asia (pp. 225-230). Penang: School of Arts, Universiti Sains Malaysia.

Pugh-Kitingan, J. (2018). The Role of Gong Ensemble Music in Shaping Ritual in Sabah: A Comparison between Dusunic and Sama-Bajau Cultures. In I. Tokoro, \& H. Tomizawa (Eds.), Islam and Cultural Diversity in Southeast Asia (Vol. 2): Perspectives from Indonesia, Malaysia, the Philippines, Thailand, and Cambodia (pp. 183-214). Tokyo: ILCAA, Tokyo University of Foreign Studies.

Pugh-Kitingan, J., \& John Baptist, J. (2005). From Coastal Communities to Interior Peoples: The Dispersion and Diffusion of the Kulintangan in Sabah. In Abdul Halim Ali (Ed.), Borneo: Kalimantan 2005; Transformasi Sosial Masyarakat-Masyarakat di Daerah Pesisir Borneo-Kalimantan; Prosiding Konferensi Antara Universiti di Borneo-Kalimantan Ke-1 (pp. 112). Kota Samarahan: Institut Pengajian Asia Timur, Universiti Malaysia Sarawak.

Pugh-Kitingan, J., Hussin, H., \& John Baptist, J. (2011). Music in the Monogit Rituals of the Kadazan of Penampang, Sabah, Malaysia. Musika Jornal, 7, 122-154. 
Pugh-Kitingan, J., Hussin, H., \& John Baptist, J. (2012). Dance as Ritual, Dance as Celebration-Tradition and Change amongst the Bajau of Semporna, Sabah. In H. Hussin, \& M. C. M. Santamaria (Eds.), Sama Celebrations: Ritual, Music and Dance of Sama Dilaut and Sama Bajau in Southern Philippines and North Borneo (pp. 93-102). Kuala Lumpur: University of Malaya Press.

Sumazau-The Kadazandusun dance. (n.d.). Retrieved from https://www.google.com/search?q=sumazau+music+and+dance+of + saba h\&source

Schulte-Fortkamp, B., \& J. Kang. (2013). Introduction to the special issue on soundscapes. The Journal of the Acoustical Society of America, 134(1), 765766.

Smith, S. J. (1994). Soundscape. Area, 26(3), 232-240.

Szeto, K. Y. (2010). Calligraphic Kinesthesia in the Dancescape: Lin Hwai-min's Cosmopolitical Consciousness in the Cursive Trilogy. Dance Chronicle, 33(3), 414-441.

Tay, P. S., Hussin, H., Khaw, L. T., Mohd. Anis Md. Nor, \& Bulan, R. (2010). Legal Protection of Traditional Cultural Expressions: A Case Study of the Kadazandusun Penampang Community. Borneo Research Journal, 4, 147-168.

Wheaton, B. (2004). Introduction: Mapping the lifestyle sport-scape. In B. Wheaton (Ed.), Understanding Lifestyle Sport (pp. 13-40). London: Routledge. 